DOI: 10.17805/ggz.2018.6.9

\title{
"Life's but a walking shadow, a poor player": проблема вариативности русских переводов пьесы «Макбет» У. Шекспира
}

И. И. Лисович

Российская академия народного хозяйства и государственной службы при Президенте РФ; Московский гуманитарный университет

Статья посвящена вариативности русских переводов «Макбета» У. Шекспира XIX-XXI вв. Степень вариативности была определена при помощи онлайн-программы (www.shakespearecorpus.ru), которая предлагает иифровые алгоритмы в качестве инструментов обработки и анализа текстов.

Стилометрический анализ был применен к корпусу из 16 переводов «Макбета» с точки зрения культурно-стилистической эпохи, жанра, способа организации художественной речи (проза / поэзия). Автор определяет, как эти факторы повлияли на вариативность. Анализ переводов монолога Макбета, раскрывающего важнейший конщепт трагедии "Life's but a walking shadow, a poor player", позволил рассмотреть на содержательном уровне стилистическую вариативность. Результаты стилометрического анализа показали при этом незначительную вариативность. В таком случае исследователю необходимо обратиться не к формальным показателям, а к анализу содержательной стороны текста.

Ключевые слова: «Макбет»; У. Шекспир; Шекспир в русских переводах; переводы; сравнительный анализ; Version Variation Visualization; вариативность; жанр; культурно-стилистическая эпоха; габитус переводчика

\footnotetext{
* Статья подготовлена в рамках проекта «Разработка и внедрение в открытом доступе онлайн-программы сравнительного тезаурусного анализа русских переводов произведений У. Шекспира», осуществляемого при поддержке РФФИ (№ 17-04-12038в).

The article was prepared within the framework of the project "Development and Launching of Open Access Online Digital Tools for Comparative Thesaurus Analysis of Russian Translations of W. Shakespeare's Works” with support from the Russian Foundation for Basic Research (no. 17-04-12038в).
} 


\title{
"Life's but a walking shadow, a poor player": Variation in Russian Translations of W. Shakespeare's "Macbeth"
}

\author{
I. I. Lisovich
}

Russian Presidential Academy of National Economy and Public Administration; Moscow University for the Humanities

The article examines the variation in Russian translations of W. Shakespeare's "Macbeth" that were made in the 19th-21st centuries. The degree of variation was determined using online digital tools (www.shakespearecorpus.ru), which offer algorithms for text processing and analysis.

The stylometric analysis was applied to the corpus of 16 translations of "Macbeth" in view of their cultural and stylistic epoch, genre, and method for artistic speech organization (prose / poetry). The author determines how these factors have influenced the variation. An analysis of the translations of Macbeth's soliloquy, which reveals the most important concept of the tragedy "Life's but a walking shadow, a poor player", has given an opportunity to consider the stylistic variability at the semantic level. The results of the stylometric analysis indicated a slight variation. In this case, the researcher should rely on the content analysis of the text rather than formal indicators.

Keywords: "Macbeth"; W. Shakespeare; Shakespeare in Russian translations; translations; comparative analysis; Version Variation Visualization; variation; genre; cultural and stylistic era; translator's habitus

\section{ВВЕДЕНИЕ}

В статьях, изданных ранее участниками проекта «Разработка и внедрение в открытом доступе онлайн-программы сравнительного тезаурусного анализа русских переводов произведений У. Шекспира» (Гайдин, 2015, 2017; Захаров, 2017; Лисович, 2017; Макаров, 2017), были рассмотрены перспективы создания корпуса русских шекспировских переводов в визуализированной среде и представлены первичные результаты исследования вариативности переводов пьес У. Шекспира, полученные при помощи инструментов онлайн-платформы Version Variation Visualization (VVV), разработанной Т. Чизманом (Tom Cheesman) и К. Флэнегеном (Kevin Flanagan) совместно с другими исследователями, занимающихся переводоведением и визуализацией больших массивов данных.

\section{ВАРИАТИВНОСТЬ РУССКИХ ПЕРЕВОДОВ ТРАГЕДИИ «МАКБЕТ»У. ШЕКСПИРА}

В 2017 г. я обратилась к переводам шекспировского «Макбета» 19301960-х гг., на которые приходится наибольшая плотность отечественных пе- 
реводов XX века. Это время расцвета сталинской эпохи, которая завершается критикой культа личности, что позволило нам обозначить конец рассматриваемого периода 1960 годом, когда был издан перевод Ю. Б. Корнеева (Лисович, 2017: 136). При анализе было сделано наблюдение, что значение основного массива показало диапазон в пределах единицы: минимальное значение вариативности $-0,5$; максимальное значение - 0,85 (см. рис. 2). Это свидетельствует о низком уровне «энтропии», в качестве которой программа воспринимает жанрово-стилистические и грамматические вариации между эпохами

Кроме того, в качестве теоретической предпосылки послужило утверждение Т. Чизмана, одного из разработчиков данной платформы, что анализ показателя вариативности демонстрирует «воздействие эпохи на жанр и стиль, поэтому ограничение корпуса по времени и жанру позволило понизить уровень помех в виде “шумов”" (Чизман, 2015: 130).

После того, как был обработан более полный корпус переводов «Макбета» XIX-XXI вв., оказалось, что в целом разница между значениями Eddy (вариативности) также осталась незначительной: минимальное значение 0,77 , максимальное значение - 1,03 (рис. 1 ):
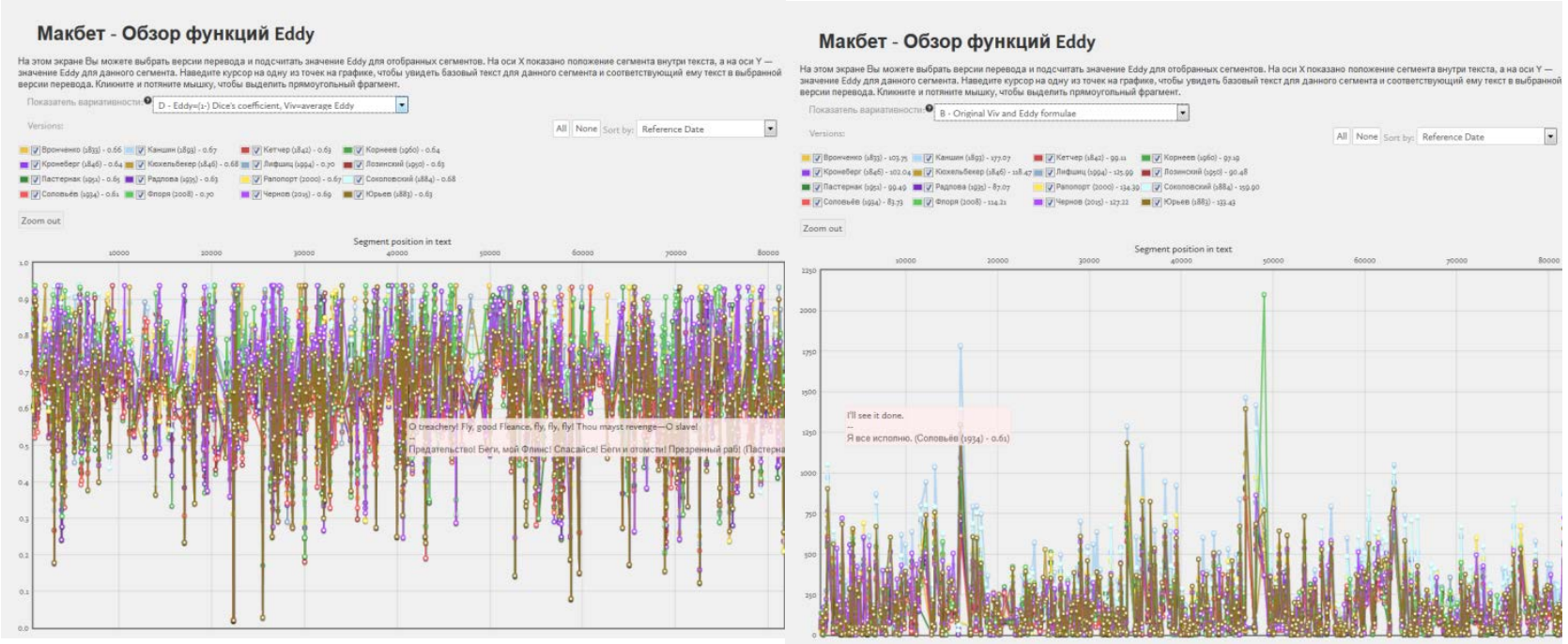

РИС. 1. «МАКБЕТ» - РЕЖИМ «ВАРИАТИВНОСТЬ»

Если сопоставить степень вариативности в пределах одной эпохи, то получим следующие данные:

- дореволюционный период: Вронченко (1833) - 0,80, Кетчер (1842) — 0,75, Кронеберг (1846) - 0,80, Кюхельбекер (1846, перевод неполный) 0,83, Юрьев (1883) - 0,84, Соколовский (1884) - 0,91, Каншин (1893) 0,94 ; 
- советский период: Соловьёв (1934) - 0,70, Радлова (1935) - 0,70, Лозинский (1950) - 0,70, Пастернак (1951) - 0,75, Корнеев (1960) - 0,71;

- постсоветский период: Лифшиц (1994) - 0,79, Рапопорт (2000) 0,85 , Флоря (2008) - 0,77, Чернов (2015) - 0,82 (рис. 2).

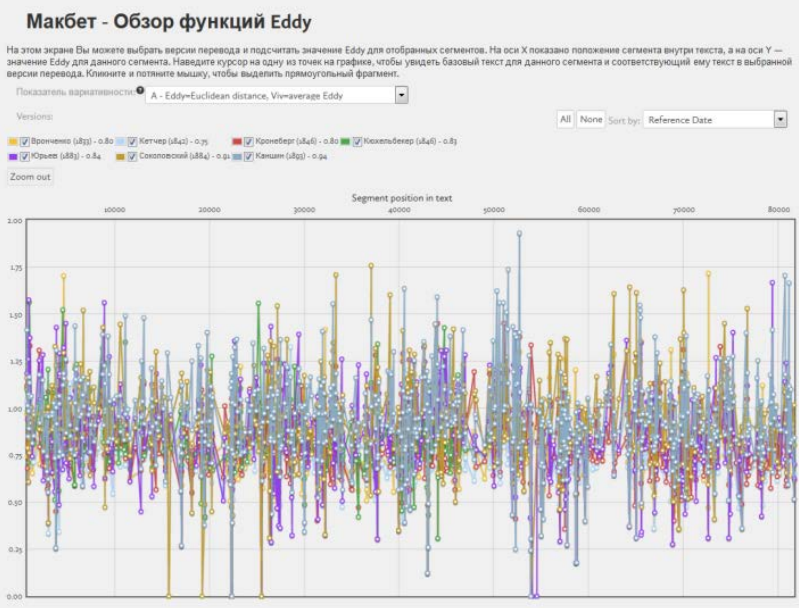

Вариативность. XIX век

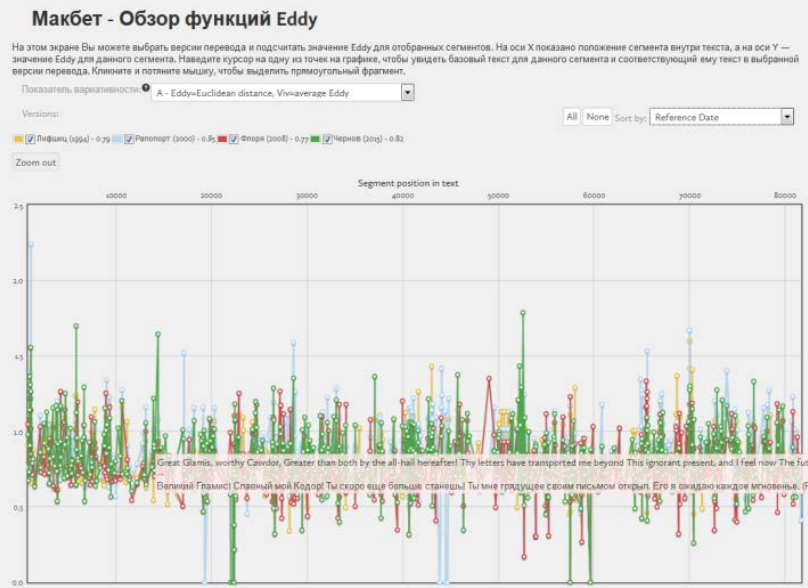

Вариативность. Постсоветский период

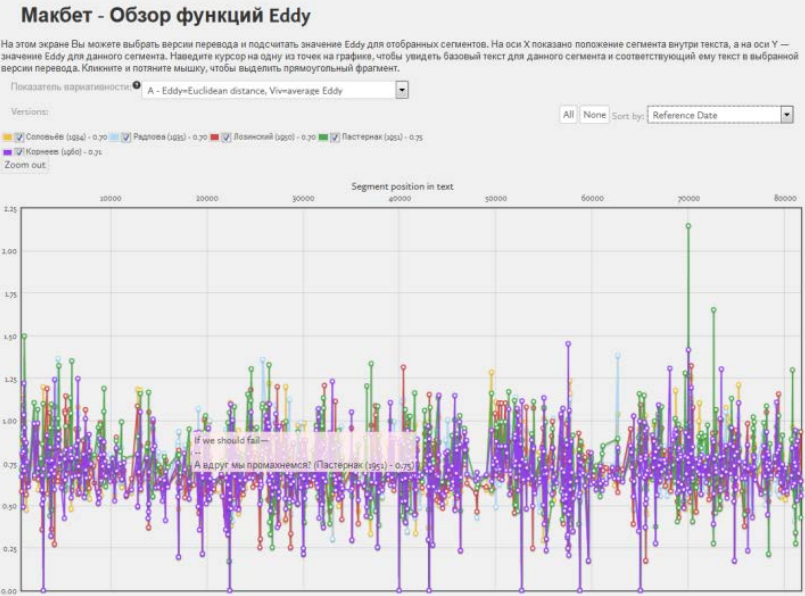

Вариативность. Советский период

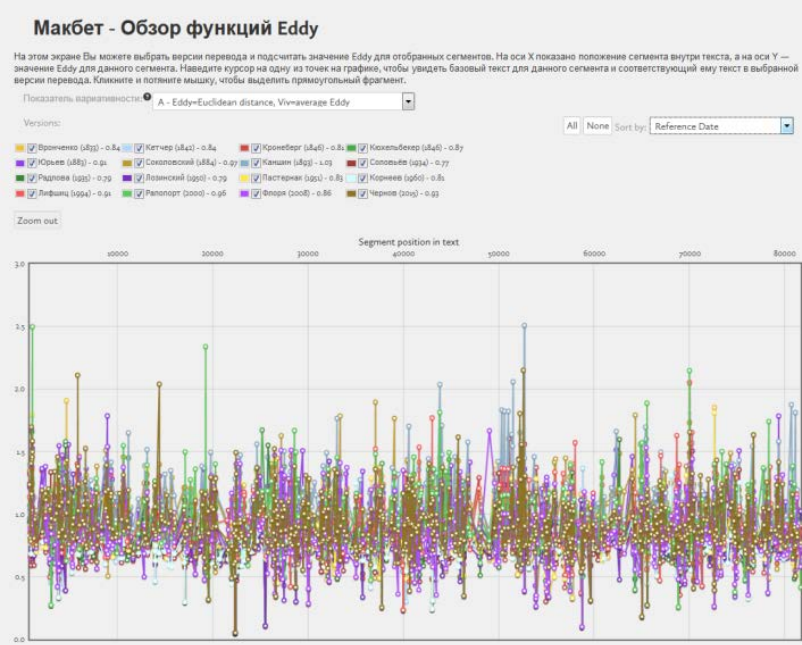

Вариативность. 16 переводов

РИС. 2. «МАКБЕТ» - РЕЖИМ «ВАРИАТИВНОСТЬ»: ГРАФИК ВАРИАТИВНОСТИ ОТДЕЛЬНЫХ СЕГМЕНТОВ

$\boldsymbol{X I X - X X I ~ в е к а : ~ В р о н ч е н к о ~ ( 1 8 3 3 ) ~ - ~ 0 , 8 4 , ~ К е т ч е р ~ ( 1 8 4 2 ) ~ - ~ 0 , 8 4 , ~ К р о н е - ~}$ берг (1846) - 0,81, Кюхельбекер (1846) - 0,87, Юрьев (1883) - 0,91, Соколовский $(1884)-0,97$, Каншин (1893) - 1,03, Соловьёв (1934) - 0,77, Радлова (1935) - 0,79, Лозинский (1950) - 0,79, Пастернак (1951) - 0.83, Корнеев (1960) - 0,81, Лифшиц (1994) - 0,91, Рапопорт (2000) - 0,96, Флоря (2008) - 0,86, Чернов (2015) - 0,93 (рис. 3). 


\section{Макбет - Обзор функций Eddy}

На этом экране Вы можете выбрать версии перевода и подсчитать значение Еddy для отобранных сегментов. На оси Хпоказано положение сегмента внутри текста, а на оси Ү значение Еddy для данного сегмента. Наведите курсор на одну из точек на графике, чтобы увидеть базовый текст для данного сегмента и соответствующий ему текст в выбранной версии перевода. Кликните и потяните мышку, чтобы выделить прямоугольный фрагмент.

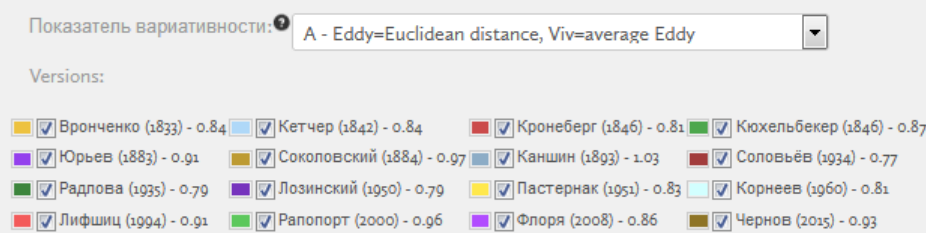

$\rightarrow$

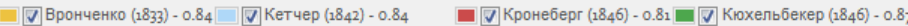

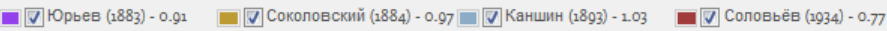

—

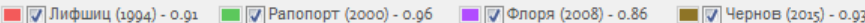

РИС. 3. «МАКБЕТ» - РЕЖИМ «ВАРИАТИВНОСТЬ»: ДАННЫЕ О ВАРИАТИВНОСТИ ПО ВОСХОДЯЩЕЙ ХРОНОЛОГИИ

У данных переводов как на примере каждого из периодов, так и в целом, незначительная вариативность в переводе длинных сегментов, а основную вариативность дают сегменты, содержащие до 30 слов, как это показывают графики «Отношение значения Viv к длине сегмента» (рис. 4). На оси X показано количество слов в сегменте, а на оси Y — значение Eddy для данного сегмента.
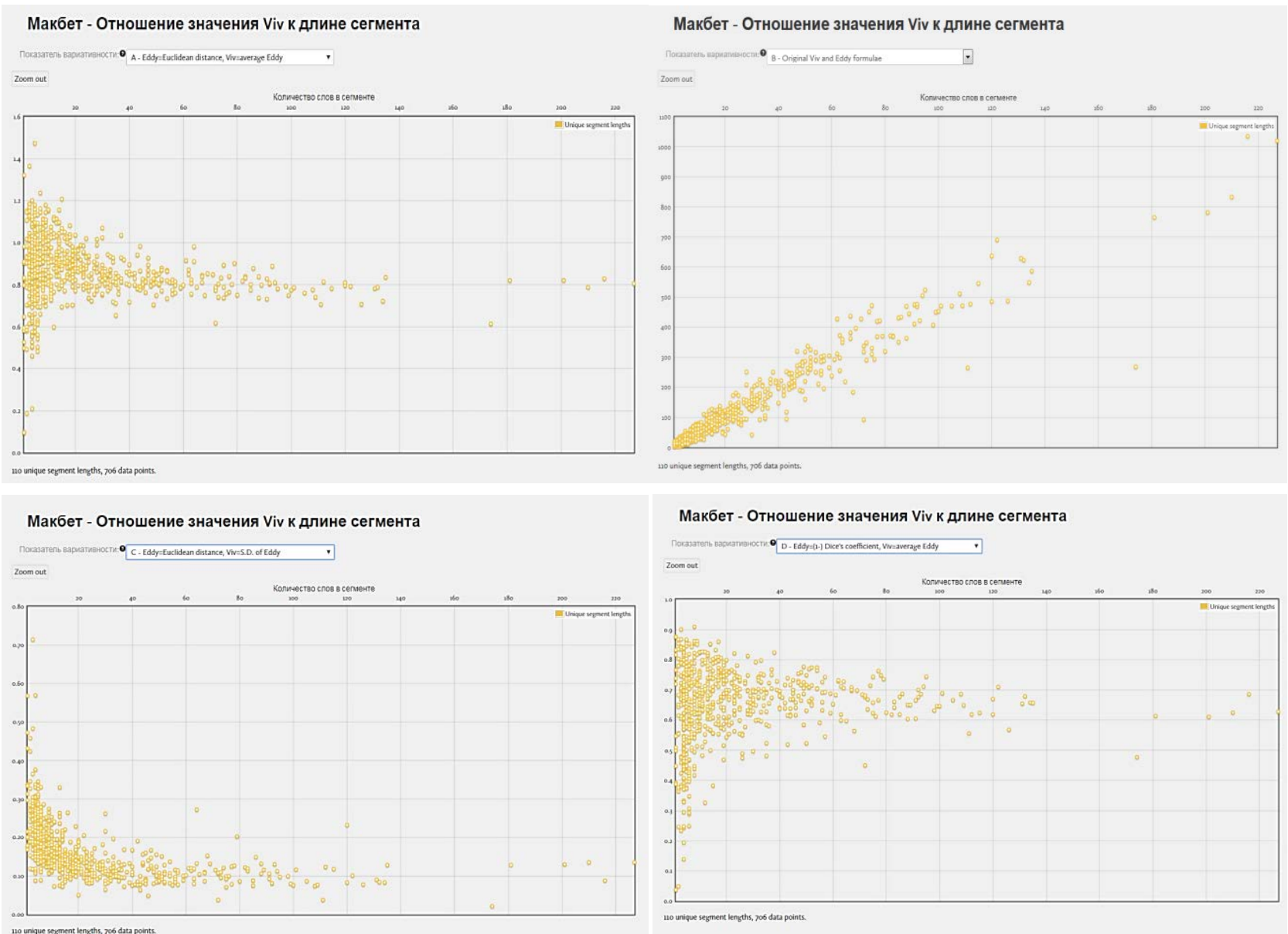

РИС. 4. «МАКБЕТ» - ОТНОШЕНИЕ ЗНАЧЕНИЯ VIV К ДЛИНЕ СЕГМЕНТА 
Можно еще раз подтвердить ранее сделанный вывод, теперь уже на материале 16 переводов, что степень вариативности не всегда находится в прямой зависимости от длины сегмента или от того, что сложно переводить на другой язык «многозначные слова, сохраняющие свою двусмысленность в этом контексте, и все они соотносятся с другими местами пьесы, еще усугубляя двусмысленность» (Чизман, 2015: 119), — как это иллюстрирует Т. Чизман на примере переводов слов "virtue", "delighted", "fair" и "black" в «Отелло» немецкими и французскими переводчиками, объясняя высокую вариативность умолчаниями или эвфемизмами, связанными с представлениями о расе, гендере, родстве, морали, эстетике, общественной иерархии и политической власти.

С точки зрения поэтической или идеологической сложности высокую вариативность могут показать переводы коротких и вполне нейтральных сегментов. Например, фраза Макдуфа “О Scotland, Scotland!” имеет показатель Viv - 1:

- дореволюционный период: Вронченко (1833) - 1,21, Кетчер (1842) - 0,83, Кронеберг (1846) - 0,85, Юрьев (1883) - 0,83, Соколовский (1884) - 1,48, Каншин (1893) - 0,85;

- советский период: Соловьёв (1934) - 0,85, Радлова (1935) - 1,59, Лозинский (1950) — 0,47, Пастернак (1951) - 1,09, Корнеев (1960) - 0,81;

- постсоветский период: Лифшиц (1994) - 1,17, Рапопорт (2000) 0,92, Флоря (2008) — 1,04, Чернов (2015) - 0,96.

Если расположить переводы по степени вариативности (значение Eddy), то порядок будет таким: Лозинский (1950) — 0,47, Корнеев (1960) — 0,81; Кетчер (1842) — 0,83, Юрьев (1883) - 0,83, Кронеберг (1846) - 0,85, Каншин (1893) - 0,85; Соловьёв (1934) - 0,85, Рапопорт (2000) - 0,92, Чернов (2015) - 0,96, Флоря (2008) - 1,04, Пастернак (1951) - 1,09, Лифшиц (1994) — 1,17, Вронченко (1833) — 1,21, Соколовский (1884) - 1,48, Радлова (1935) - 1,59.

Как показывает рисунок (рис. 5), разброс от 0,47 до 1,59 не объясняется стилистическим различием эпох. Наиболее точно перевели Н. Х. Кетчер, П. А. Каншин и С. М. Соловьёв, а у А. В. Флори - «О Боже!», тогда как у М. П. Вронченко фигурирует «Бедная отчизна», у Б. Л. Пастернака - «Бедный край», а самый длинный вариант встречаем у А. Д. Радловой («О край мой! Край шотландский!») и Ю. И. Лифшица («Увы, мой край! Шотландия моя!»). Эти различия, скорее, можно объяснить поэтической вольностью и / или эмоциональностью переводчика, возможно, намеком на свою страну в том случае, когда Шотландия не упоминается. 
เทா VIV 0

A - Euclidean distance $\checkmark$
- Дата просмотра

Минимальное значение Viv:

Apply 0

With other graces weighed.

MALCOLM

But I have none. The king-becoming graces,

As justice, verity, temp'rance, stableness,

Bounty, perseverance, mercy, lowliness,

Devotion, patience, courage, fortitude,

I have no relish of them but abound

In the division of each several crime

Acting it many ways. Nay, had I power, I should

Pour the sweet milk of concord into hell,

Uproar the universal peace, confound

All unity on earth.

MACDUFF

O Scotland, Scotland

MALCOLM

If such a one be fit to govern, speak.

I am as I have spoken.

MACDUFF

Fit to govern?

No, not to live. -O nation miserable

With an untitled tyrant bloody-sceptered

When shalt thou see thy wholesome days again

Since that the truest issue of thy throne

By his own interdiction stands accursed

And does blaspheme his breed?-Thy royal father

Was a most sainted king. The queen that bore thee

Oft'ner upon her knees than on her feet,

Died every day she lived. Fare thee well.

These evils thou repeat'st upon thyself

Hath banished me from Scotland. $-\mathrm{O}$ my breast,

TИП VIV $\bullet$

A - Euclidean distance -

Минимальное значение Viv:

Максимальное значение Viv:

Apply 0

\section{This avarice}

ticks deeper, grows with more pernicious root

Than summer-seeming lust, and it hath been

The sword of our slain kings. Yet do not fear.

Scotland hath foisons to fill up your will

Of your mere own. All these are portable,

With other graces weighed

MALCOLM

But I have none. The king-becoming graces

As justice, verity, temp'rance, stableness,

As justice, verity, temp'rance, stableness,

Devotion, patience, courage, fortitude

Devotion, patience, courage, fortitude

have no relish of them but abound
In the division of each several crime,

In the division of each several crime,

Pour the sweet milk of concord into hell,

Uproar the universal peace, confound

All unity on earth.

MACDUFF

O Scotland, Scotland!

MALCOLM

If such a one be fit to govern, speak

I am as I have spoken.

MACDUFF

Fit to govern?

No, not to live. $-\mathrm{O}$ nation miserable

With an untitled tyrant bloody-sceptered,

When shalt thou see thy wholesome days again.

Since that the truest issue of thy throne

By his own interdiction stands accursed

Вронченко (2833) Backtranslation Microsofte Transiate
Бедная отчизна!

\subsection{7}

Кетчер (1842)

Backtranslation Misrosofie Translate

О, Шотландия, Шотландия!

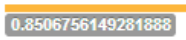

Кронеберг (1846)

Шотландия! Шогландия!

ranslation Microsofte Translate

3.

0.8322472428211747

Юрьев (1883)

Backtranslation Mierosofte Translate

О, Шотландия, Шотландия!

कै.

Соколовский (1884) Backtranslation Microsofiø Translaze

0 , край, родимый край!

3

0.8506756149281882

- Дата просмотра

\begin{tabular}{l}
\hline 0.8506756149281883 \\
Каншин (2893) \\
Шотландия, Шотландия!
\end{tabular}

\subsection{8}

Соловьёв (1934)

Шогландия! Шотландия!

Backtranslation Microsofte Transla

1.5979509354744759
Радлова (1935) Backtranslation Microsofto Transize

О край мой! Край шотландский!

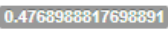

Лозинский (1950)

ОШотландия

Backtranslation Microsefte Translase

О бетньй край!

3 
This avarice

Sticks deeper, grows with more pernicious root

Than summer-seeming lust, and it hath been

The sword of our slain kings. Yet do not fear.

Scotland hath foisons to fill up your will

Of your mere own. All these are portable,

With other graces weighed.

MALCOLM

But I have none. The king-becoming graces,

As justice, verity, temp'rance, stableness,

Bounty, perseverance, mercy, lowliness,

Devotion, patience, courage, fortitude,

have no relish of them but abound

In the division of each several crime,

Acting it many ways. Nay, had I power, I shoul

Pour the sweet milk of concord into hell,

uproar the universal peace, confound

All unity on earth,

MACDUFF

O Scotland, Scotland!

MALCOLM

If such a one be fit to govern, speak

I am as I have spoken.

MACDUFF

Fit to govern?

No, not to live. $-O$ nation miserable

With an untitled tyrant bloody-sceptered

When shalt thou see thy wholesome days again

Since that the truest issue of thy throne

By his own interdiction stands accursed

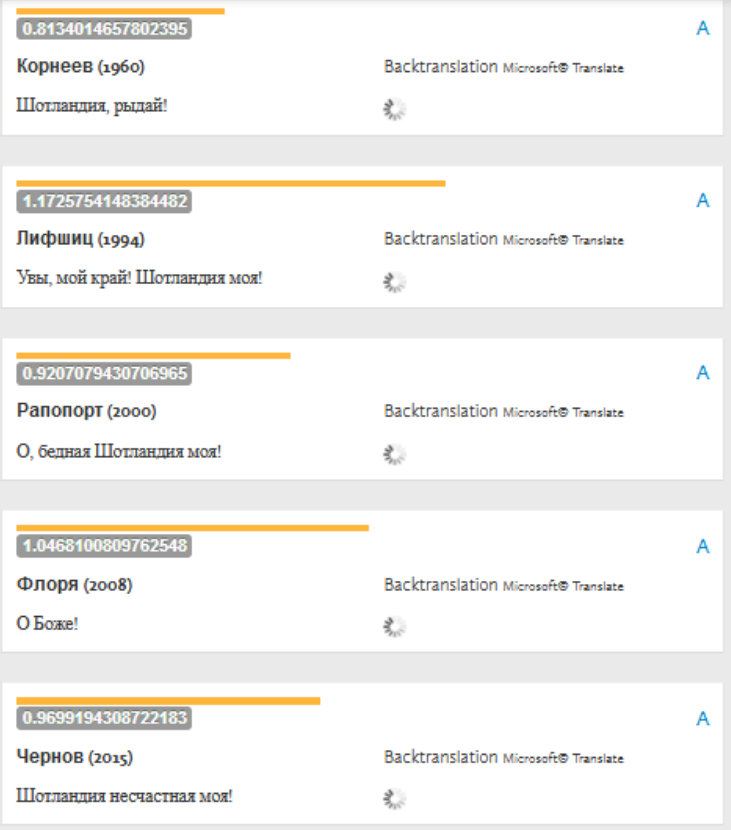

РИС. 5. ВАРИАТИВНОСТЬ СЕГМЕНТА “О SСОTLAND, SCOTLAND!”, РАНЖИРОВАННАЯ ПО ГОДАМ ПЕРЕВОДОВ ПО ВОСХОДЯЩЕЙ

В вышеупомянутой статье прошлого года я объясняла низкую вариативность советских переводов близостью габитусов переводчиков, принадлежащих к одной культурно-исторической эпохе (Бурдье, 2001). В какой-то степени этот вывод подтверждается: переводы советского периода находятся довольно близко — в пределах $0,77-0,81$. Но общую незначительную степень вариативности переводов можно объяснить преемственностью языковой и стилистической традиции, заложенной в XIX в. - в эпоху формирования русского литературного и поэтического языка, который для переводчиков $\mathrm{XX}$ века рассматривался как архаизированный язык, чья стилистика позволяет передать высокий стиль трагедии и шекспировскую эпоху, заложившую основания национального английского языка. Кроме того, вариативность перевода в нашем случае может зависеть от жанровой принадлежности, например, у комедий, как показывает данная программа, степень вариативности может быть выше. Например, «Бесплодные усилия любви» (данные любезно предоставлены В. С. Макаровым) показывают вариативность советских переводов в пределах $0,84-1,03$ (рис. 6). 


\section{Бесплодные усилия любви - Обзор функций Eddy}

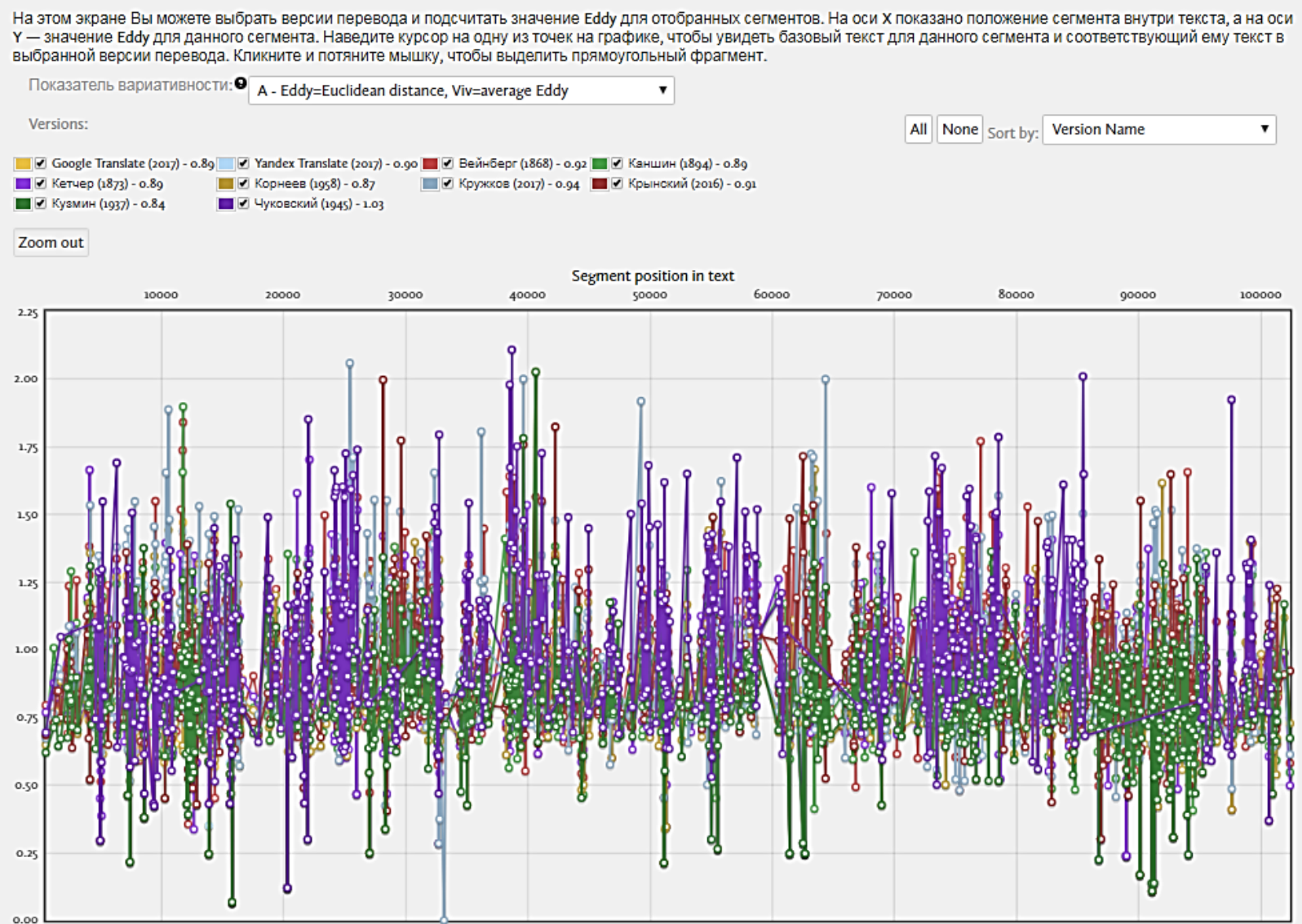

РИС. 6. «БЕСПЛОДНЫЕ УСИЛИЯ ЛЮБВИ» РЕЖИМ «ВАРИАТИВНОСТЬ»

Онлайн-программа сравнительного тезаурусного анализа русских переводов произведений У. Шекспира на основе платформы Version Variation Visualisation (VVV) показывает, что во всех приведенных переводах «Макбета» их вариативность (значения Eddy) незначительно колеблется между 0,77 и 1,03. Притом степень вариативности не сильно зависит от времени выполнения перевода: в диапазон с более высокой вариативностью попали версии П. А. Каншина (1893), А. Л. Соколовского (1884), В. Н. Рапопорта (2000) и А. Ю. Чернова (2015), с наименьшей — С. М. Соловьёва (1934), М. Л. Лозинского (1950) и А. Д. Радловой (1935). Невозможно утверждать, что наиболее ранние переводы XIX века обладают большей вариативностью, также как и наиболее поздние XXI века - наименьшей. Т. е. вариативность в данном случае не зависит от времени создания перевода.

Тем не менее, между переводами различных веков есть незначительные различия. С точки зрения организации речи наибольшую вариативность показал прозаический перевод П. А. Каншина (1893) - 1,03, тогда как перевод в прозе Н. Х. Кетчера (1842) оказался в рамках общей динамики - 0,84. Это 
могло произойти, например, из-за того, что Каншин увеличил объем монолога Макбета “If it were done when 'tis done...” (рис. 7), тогда как Кетчер остается в рамках объема шекспировского оригинала (рис. 8).

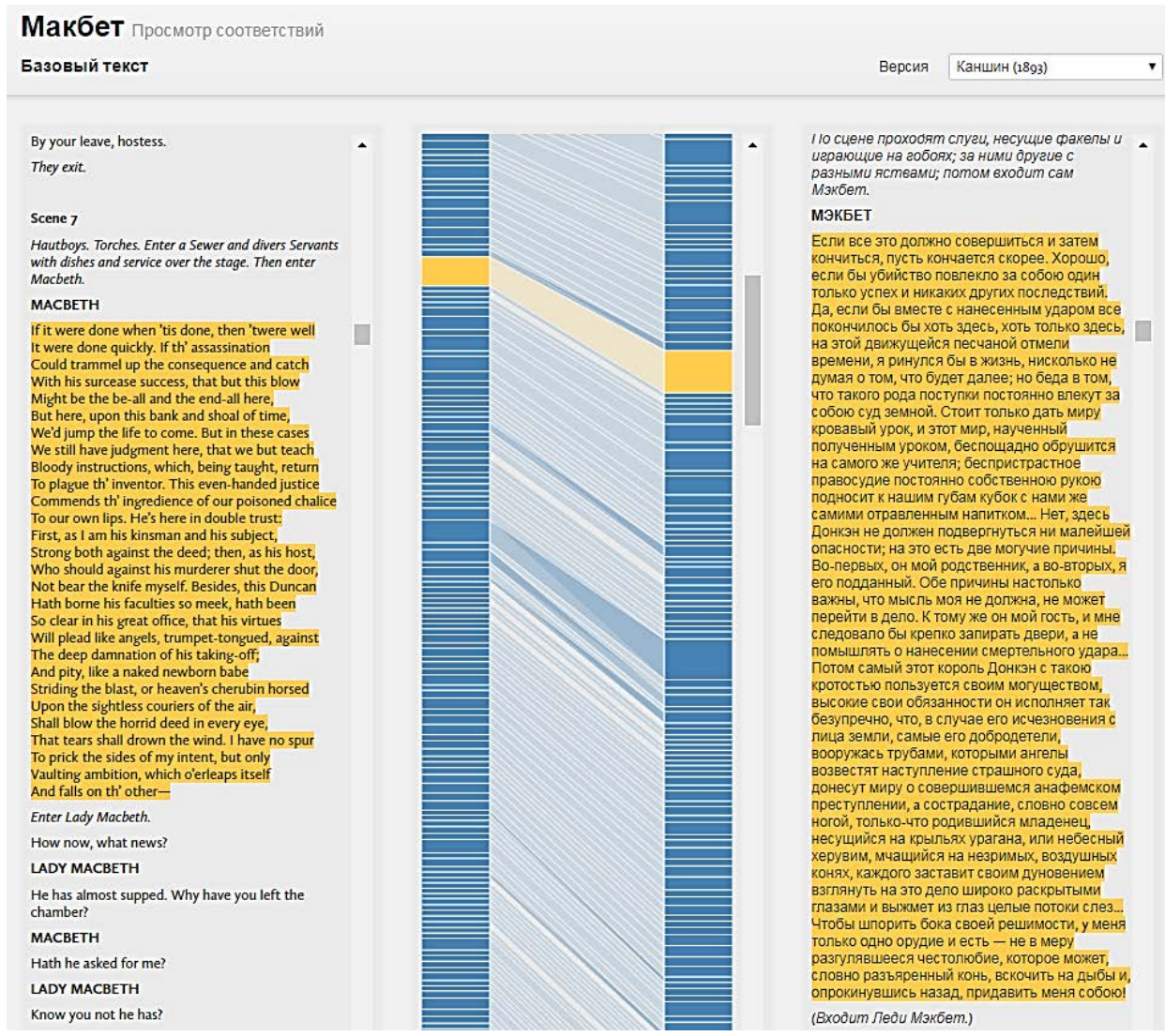

\section{РИС. 7. ПЕРЕВОД П. А. КАНШИНА - РЕЖИМ «ПРОСМОТР СООТВЕТСТВИЙ»}

Макбет Просмотр соответствий

Базовый текст

Версия Кетчер (1842)

MACDetn.

If it were done when 'tis done, then 'twere well

'were done quickly. If th' assassination

With his surcease success, that but this blow

Might be the be-all and the end-all here,

But here, upon this bank and shoal of time,
We'd jump the life to come. But in these cases

We still have judgment here, that we but teach

Bloody instructions, which, being taught, return

To plague th' inventor. This even-handed justice
Commends th' ingredience of our poisoned chalice

Commends th' ingredience of our poisoned
To our own lips. He's here in double trust:

First, as I am his kinsman and his subject,

Strong both against the deed; then, as his host,
Who should gagainst his murderer shut the doo

Who should against his murderer shut the door,
Not bear the knife myself. Besides, this Duncan

Hath borne his faculties so meek, hath been

So clear in his great office, that his virtues

Will plead like angels, trumpet-tongued, against

The deep damnation of his taking-off

And pity, like a naked newborn babe

Upon the sightless couriers of the air,

Shall blow the horrid deed in every eye,

That tears shall drown the wind. I have no spu To prick the sides of my intent, but only

And falls on th' other-

Enter Lady Macbeth.
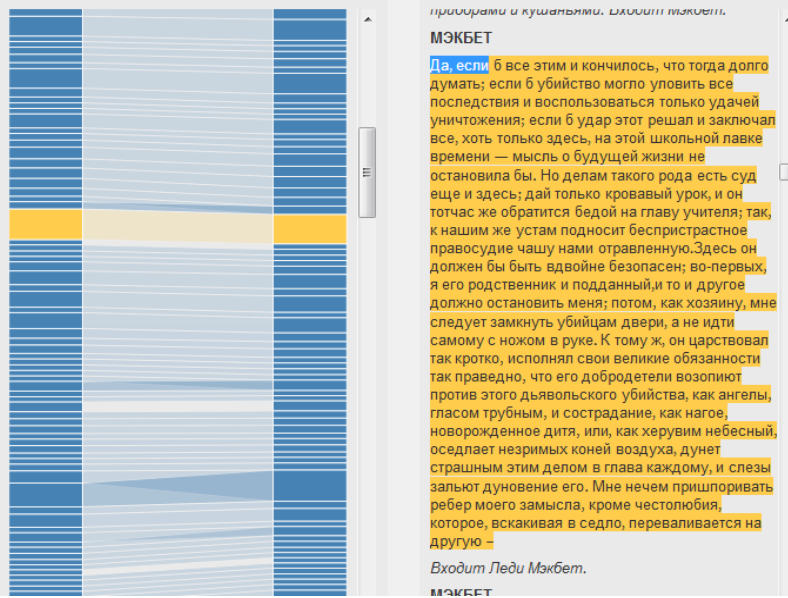

РИС. 8. ПЕРЕВОД Н. Х. КЕТЧЕРА РЕЖИМ «ПРОСМОТР СООТВЕТСТВИЙ» 
Данные вариативности с точки зрения хронологии позволили выявить группы переводов, близкие по степени вариативности, они принадлежат переводчикам, сформировавшимся в рамках одной культурно-стилистической эпохи, как показывает рис. 9.

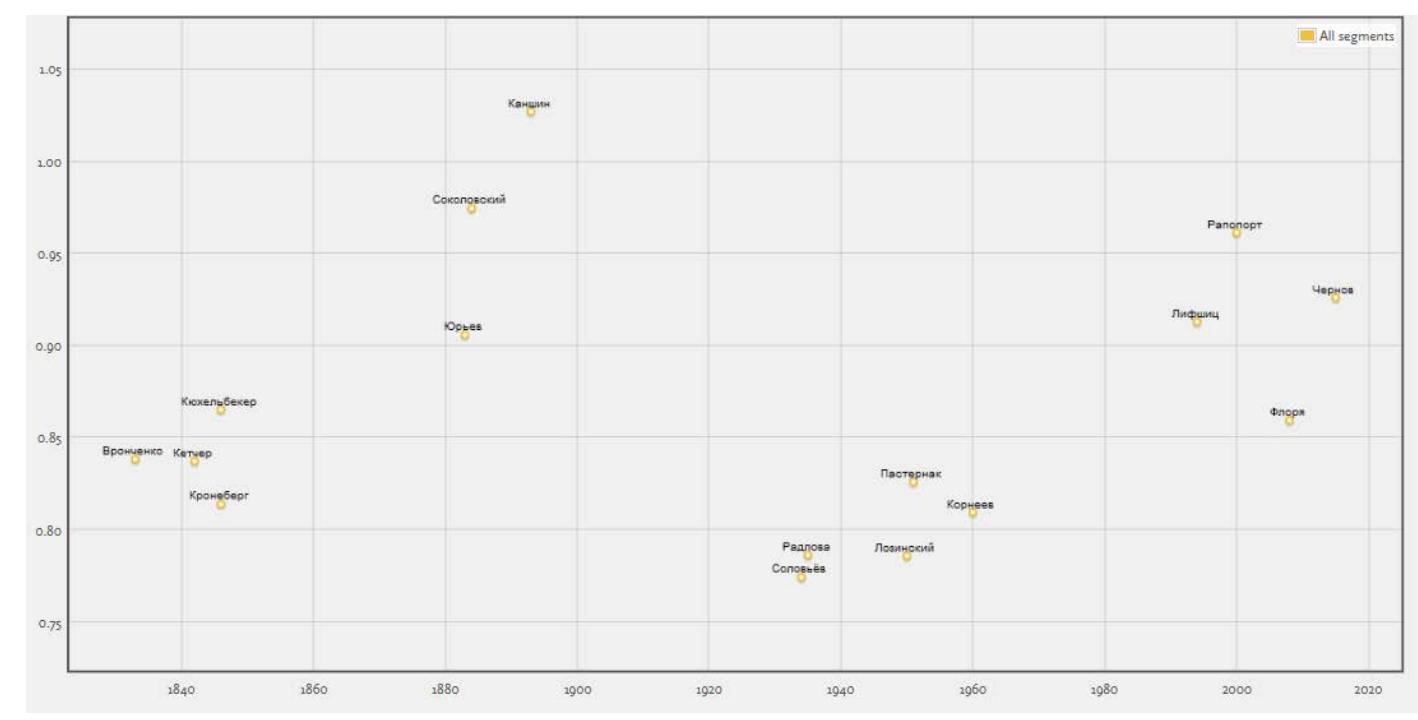

РИС. 9. РЕЖИМ «ИСТОРИЯ ЕDDY» (В ИСТОРИЧЕСКОЙ ПОСЛЕДОВАТЕЛЬНОСТИ ПЕРЕВОДОВ)

\author{
МОНОЛОГ МАКБЕТА \\ "SHE SHOULD HAVE DIED HEREAFTER..." \\ В РУССКИХ ПЕРЕВОДАХ
}

Если обратиться к ключевым концептуальным моментам пьесы, то можно показать диапазон их интерпретации с точки зрения соотношения стилистического решения и вариативности переводов. Одним из важнейших в развитии не только его образа, но и для философии человеческого бытия, восприятия времени, эпохи, для соизмеримости человеческих деяний со временем, для ответов на предельные вопросы трагедии является известный монолог Макбета, узнавшего о смерти королевы $(\mathrm{V}, 5)$ :

She should have died hereafter;

There would have been a time for such a word.

Tomorrow and tomorrow and tomorrow

Creeps in this petty pace from day to day

To the last syllable of recorded time,

And all our yesterdays have lighted fools

The way to dusty death. Out, out, brief candle!

Life's but a walking shadow, a poor player

That struts and frets his hour upon the stage 
And then is heard no more. It is a tale

Told by an idiot, full of sound and fury,

Signifying nothing.

Вот как он выглядят показатели его вариативности, ранжированной в порядке возрастания:

- $\quad$ 0,70 - Кронеберг (1846): Она могла бы умереть и позже; / Всегда б прийти поспела эта весть... / Да! завтра, завтра — и все то же завтра / Скользит невидимо со дня на день / И по складам отсчитывает время; / А все вчера глупцам лишь озаряли / Дорогу в гроб. Так догорай, огарок! / Что жизнь? - тень мимолетная, фигляр, / Неистово шумящий на помосте / И через час забытый всеми: сказка / В устах глупца, богатая словами / И звоном фраз, но нищая значеньем!

- $\quad$ 0,74 - Лозинский (1950): Ей надлежало бы скончаться позже: / Уместнее была бы эта весть. / Бесчисленные «завтра», «завтра», «завтра» / Крадутся мелким шагом, день за днем, / К последней букве вписанного срока; / И все «вчера» безумцам освещали / Путь к пыльной смерти. Истлевай, огарок! / Жизнь - ускользающая тень, фигляр, / Который час кривляется на сцене / И навсегда смолкает; это - повесть, / Рассказанная дураком, где много / И шума и страстей, но смысла нет.

- $\quad$ 0,754 - Корнеев (1960): Что б умереть ей хоть на сутки позже! / Не до печальной вести мне сегодня. / Так - в каждом деле. Завтра, завтра, завтра, - / А дни ползут, и вот уж в книге жизни / Читаем мы последний слог и видим, / Что все вчера лишь озаряли путь / К могиле пыльной. Дотлевай, огарок! / Жизнь - это только тень, комедиант, / Паясничавший полчаса на сцене / И тут же позабытый; это повесть, / Которую пересказал дурак: / В ней много слов и страсти, нет лишь смысла.

- $\quad$ 0,755 - Соловьёв (1934): Она могла бы умереть попозже, / Тогда бы время было у меня / Для этой вести. - Завтра, завтра, завтра / День ото дня влачится мелким шагом / Вплоть до последней буквы в книге жизни. / И все вчера лишь освещали путь / Туда, где прах. Так догорай, огарок! / Жизнь - только тень минутная; фигляр / Свой краткий час шумящий на помосте, / Чтобы навек затихнуть; это - сказка / В устах глупца, где много звонких фраз, / Но смысла нет.

- $\quad$ 0,76 - Вронченко (1833): Да? она бы умереть / Могла и позже — и для этой вести / Настал бы час приличный! Завтра, завтра, / И снова завтра - день за днем, до утра / Последнего, идет неслышным шагом, / И каждое вчера, как порассудишь, / Нам освещало только путь ко гробу! / Потухни ж, факел! Что есть жизнь? - мечта; / Актер, поющий, плачущий на сцене / В урочный час, и чрез миг забытый; / Рассказ, сложенный дурачком - задорный / И многословный, но без всякой мысли!

- $\quad$ 0,79 - Флоря (2008): Скончаться б ей попозже: я сейчас / Не вправе расслабляться. Если б завтра, / Все завтра, завтра... Глядь: уже «вчера» — / Вся жизнь 
твоя. Дошла до эпилога / Трагедия. Огарок догорел. / Жизнь - это призрак, балаган пошлейший: / Марионетки пляшут, а потом / Их убирают в ящик. Жизнь - новелла, / Безумцем пересказанная: бред / И беснование.

- 0,802 - Пастернак (1951): Не догадалась умереть попозже, / Когда б я был свободней, чем сейчас! / Мы дни за днями шепчем: «Завтра, завтра» / Так тихими шагами жизнь ползет / К последней недописанной странице. / Оказывается, что все «вчера» / Нам сзади освещали путь к могиле. / Конец, конец, огарок догорел! / Жизнь - только тень, она - актер на сцене. / Сыграл свой час, побегал, пошумел - / И был таков. Жизнь - сказка в пересказе / Глупца. Она полна трескучих слов / И ничего не значит.

- $\quad$ 0,806 - Юрьев (1883): Могла-бы умереть и позже! Время / Своей чредой успело бы настать / И для такого слова! - Завтра, завтра / И завтра! Медленно ползет день за днем / И до последней буквы в книге жизни; / И наши все вчера лишь освещали / Глупцам путь незаметный к праху смерти! — / Так гасни ж, гасни, крохотный огарок! — / Жизнь — тень лишь мимолетная! - актер / Прежалкий на подмостках: час один / Урочный, величаясь, пошумит / Иль в гневе грозном покричит, а там / Пропал - его уже не слышно! - сказка / Глупца, неистовств полная и грома, / А содержанья никакого!..

- 0,81: Лифшиц (1994): Она б могла и позже опочить. / Печалиться мне нынче недосуг. / Вот если б завтра... завтра... завтра... завтра... / Разматывая свиток бытия, / Крадутся дни к итоговой ремарке, / И «завтра», превращаясь во «вчера», / Толкает нас в могилу. И - конец. / Туман исчез. Растаяла свеча. / Сгорела жизнь - бездарный лицедей: / Валял себе на сцене дурака, / А время вышло — канул за кулисы. / Пропала жизнь - бессмысленная сказка, / Рассказанная круглым идиотом, / Безумный и бессвязный монолог.

- $\quad$ 0,82 - Кетчер (1842): Как будто не могла она умереть немного попозже; было бы еще время и для этой вести. Завтра и завтра, и опять завтра тащится едва заметными шагом ото дня ко дню до последнего слога в книге судеб, и все наши вчера освещали глупцам дорогу к пыльной смерти. Догорай же, догорай крошечный огарок! Жизнь - это тень мимолетная, это жалкой комедиант, который пробеснуется, провеличается свой час на помосте, и за тем не слышен; это сказка рассказываемая глупцом, полная шума и неистовства ничего не значащих.

- $\quad$ 0,86 - Радлова (1935): Она могла бы умереть попозже; / Тогда для слов таких нашлось бы время. / Всё завтра, да всё завтра, да всё завтра... / Плетутся мелкими шажками дни / До слов последних в книге нашей жизни. / А все «вчера» глупцам путь освещали / В смерть тленную. Погасни же, огарок! / Жизнь - тень бегущая; актер несчастный, / Что час свой чванится, горит на сцене, — / И вот уж он умолк навек; рассказ, / Рассказанный кретином с пылом, с шумом, / Но ничего не значащий. 
- $\quad$ 0,87 - Рапопорт (2000): Ей следовало после умереть, / Когда бы смерть пришлась бы больше в пору. / О, эти завтра, завтра, завтра... / День ото дня они вползают / К нам незаметно через поры бытия. / И получается, что наши все вчера / На то лишь и пригодны только, / Чтоб освещать к могиле путь для дураков. / О, угасай, короткая свеча. / Жизнь - только тень бродячая, / Она - актер несчастный, / Которому отмерен краткий срок / Носиться или шествовать на сцене, / Но вот уж больше не слыхать его. / Она - история, что рассказал дурак, / Наполненная яростью и шумом, / Которая не значит ничего.

- $\quad$ 0,92 - Каншин (1893): Не могла она подождать хоть немного? Всегда было бы время услыхать такое известие и позже... Завтра, послезавтра, а затем опять завтра; тихим, едва заметным шагом крадется день за днем до самого последнего слога в росписях времени, и все наши «вчера» только и делали, что освещали перед безумцами дорогу к смерти, обращающей в прах все живое. Угасай же, угасай скорее, догорающий огарок!.. Жизнь не более, как блуждающий призрак, жалкий фигляр, который в указанный час покрасуется, поломается на подмостках, а когда сойдет с них, о нем больше нет и помина; это сказка, рассказанная идиотом; много в ней треска, много неистовства, но смысла ровно никакого.

- $\quad$ 0,96 - Соколовский (1884): Поздней бы должно / Ей умереть! Для этаких известий / Всегда найдется время! - завтра, завтра!.. / Все завтра без конца, и так плетется, / Чуть видным шагом, время до минуты, / Когда сказать придется нам: «прощай» / Всему, что было! — и глупцы не видят, / Что все, чем занимались мы вчера, / Служило только факелом, светившим / В пути к могиле нам!.. Прочь, глупый факел!.. / Довольно ты горел! Вся наша жизнь - / Пустая тень! актер, что корчит рожи / На гаерских подмостках!.. Минет час, / И нет его! Жизнь - сказка, что бормочет / Глупец другим глупцам!.. Из всех он сил / Старается занять их, иль встревожить, / И ничего в конце не выйдет, кроме / Глупейших пустяков!..

- 1,13 - Чернов (2015): Ей стоило умереть после битвы, / Сейчас её смерть неуместна. / И завтра будет завтра, / С ещё раз завтра, и ещё, и ещё, и ещё. / День за днём, день за днём, день за днём, / Потчуют нас бессмысленными / Завтраками, обедами и ужинами. / И так до последнего слога Книги су́деб. А каждое «вчера» освещает / Глупцам путь в преисподнюю. / Огарок догорает... догорает... Вот и догорел!.. / Жизнь - всего лишь плоская тень, / Игра бездарного актера, / Что откривлялся да и сгинул. / Бессмысленный вопль, / Наполненный шумом и яростью, / Сюжет, пересказанный идиотом.

Таким образом, перевод А. Ю. Чернова по степени вариативности $(1,13)$ наиболее близок версии А. Л. Соколовского $(0,96)$.

Макбет рефлексирует над вязкой повседневностью, чей смысл постоянно ускользает от человека, погруженного в ее замедленное настоящее. Шаги времени незаметно приближают его к «завтра», а оно оказывается моги- 
лой, свет которой уже иначе освещает пройденный путь. Русские переводы пытаются ухватить связь между ключевыми концептами монолога (“syllable of recorded time”, "brief candle”, "walking shadow”, "poor player”, "a tale told by an idiot”), с помощью которых Макбет описывает жизнь. С одной стороны, перед нами топосы барочного стиля, с другой, здесь можно увидеть и христианские, платонические и ренессансные аллюзии.

В русских переводах ключевые слова звучат так:

\begin{tabular}{|c|c|c|c|c|}
\hline & $\begin{array}{l}\text { syllable of record- } \\
\text { ed time }\end{array}$ & $\begin{array}{l}\text { walking shad- } \\
\text { ow }\end{array}$ & poor player & $\begin{array}{l}\text { a tale told by an } \\
\text { idiot, full of sound } \\
\text { and fury, signify- } \\
\text { ing nothing. }\end{array}$ \\
\hline $\begin{array}{l}\text { Вронченко } \\
0,76 \\
(1833)\end{array}$ & $\begin{array}{l}\text {..до утра / По- } \\
\text { следнего, идет не- } \\
\text { слышным ша- } \\
\text { гом... }\end{array}$ & мечта & актер & $\begin{array}{l}\text { Рассказ, сложен- } \\
\text { ный дурачком - } \\
\text { задорный / И мно- } \\
\text { гословный, но без } \\
\text { всякой мысли! }\end{array}$ \\
\hline $\begin{array}{l}\text { Кетчер } \\
0,82 \\
(1842)\end{array}$ & $\begin{array}{l}\text {...до последнего } \\
\text { слога в книге су- } \\
\text { деб... }\end{array}$ & $\begin{array}{l}\text { тень мимолет- } \\
\text { ная }\end{array}$ & $\begin{array}{l}\text { жалкой ко- } \\
\text { медиант }\end{array}$ & $\begin{array}{l}\text {...сказка расска- } \\
\text { зываемая глупцом, } \\
\text { полная шума и } \\
\text { неистовства ниче- } \\
\text { го не значащих. }\end{array}$ \\
\hline $\begin{array}{l}\text { Кронеберг } \\
0,70 \\
(\mathbf{1 8 4 6 )}\end{array}$ & $\begin{array}{l}\text { И по складам от- } \\
\text { считывает вре- } \\
\text { мя... }\end{array}$ & $\begin{array}{l}\text { тень мимолет- } \\
\text { ная }\end{array}$ & фигляр & $\begin{array}{l}\text {...сказка / В устах } \\
\text { глупца, богатая } \\
\text { словами / И зво- } \\
\text { ном фраз, но ни- } \\
\text { щая значеньем! }\end{array}$ \\
\hline $\begin{array}{l}\text { Юрьев } \\
\mathbf{0 , 8 0} \\
(\mathbf{1 8 8 3 )}\end{array}$ & $\begin{array}{l}\text { И до последней } \\
\text { буквы в книге } \\
\text { жизни... }\end{array}$ & $\begin{array}{l}\text { тень лишь ми- } \\
\text { молетная }\end{array}$ & $\begin{array}{l}\text { актер пре- } \\
\text { жалкий }\end{array}$ & $\begin{array}{l}\text {...сказка / Глупца, } \\
\text { неистовств полная } \\
\text { и грома, / А со- } \\
\text { держанья никако- } \\
\text { го!.. }\end{array}$ \\
\hline $\begin{array}{l}\text { Соколовский } \\
0,96 \\
(1884)\end{array}$ & $\begin{array}{l}\text {...время до мину- } \\
\text { ты, / Когда сказать } \\
\text { придется нам: } \\
\text { «прощай» / Всему, } \\
\text { что было! }\end{array}$ & пустая тень & $\begin{array}{l}\text { актер, что } \\
\text { корчит ро- } \\
\text { жи }\end{array}$ & $\begin{array}{l}\text {...сказка, что бор- } \\
\text { мочет / Глупец } \\
\text { другим глупцам!.. }\end{array}$ \\
\hline $\begin{array}{l}\text { Каншин } \\
0,92\end{array}$ & $\begin{array}{l}\text {...день за днем до } \\
\text { самого последнего }\end{array}$ & $\begin{array}{l}\text { блуждающий } \\
\text { призрак }\end{array}$ & $\begin{array}{l}\text { жалкий } \\
\text { фигляр }\end{array}$ & $\begin{array}{l}\text {...сказка, расска- } \\
\text { занная идиотом; }\end{array}$ \\
\hline
\end{tabular}




\begin{tabular}{|c|c|c|c|c|}
\hline (1893) & $\begin{array}{l}\text { слога в росписях } \\
\text { времени... }\end{array}$ & & & $\begin{array}{l}\text { много в ней трес- } \\
\text { ка, много неистов- } \\
\text { ства, но смысла } \\
\text { ровно никакого. }\end{array}$ \\
\hline $\begin{array}{l}\text { Соловьев } \\
0,75 \\
(1934)\end{array}$ & $\begin{array}{l}\text {...до последней } \\
\text { буквы в книге } \\
\text { жизни. }\end{array}$ & тень минутная & фигляр & $\begin{array}{l}\text {...сказка / В устах } \\
\text { глупца, где много } \\
\text { звонких фраз, / Но } \\
\text { смысла нет. }\end{array}$ \\
\hline $\begin{array}{l}\text { Радлова } \\
\text { 0,86 } \\
\text { (1935) }\end{array}$ & $\begin{array}{l}\text {...дни / До слов } \\
\text { последних в книге } \\
\text { нашей жизни. }\end{array}$ & тень бегущая & $\begin{array}{l}\text { актер } \\
\text { несчастный }\end{array}$ & $\begin{array}{l}\text {...рассказ, / Рас- } \\
\text { сказанный крети- } \\
\text { ном с пылом, с } \\
\text { шумом, / Но ниче- } \\
\text { го не значащий. }\end{array}$ \\
\hline $\begin{array}{l}\text { Лозинский } \\
\mathbf{0 , 7 4} \\
(1950)\end{array}$ & $\begin{array}{l}\text {...день за днем, / } \\
\text { К последней букве } \\
\text { вписанного сро- } \\
\text { ка... }\end{array}$ & $\begin{array}{l}\text { ускользающая } \\
\text { тень }\end{array}$ & фигляр & $\begin{array}{l}\text {...повесть, / Рас- } \\
\text { сказанная дура- } \\
\text { ком, где много / И } \\
\text { шума и страстей, } \\
\text { но смысла нет. }\end{array}$ \\
\hline $\begin{array}{l}\text { Пастернак } \\
0,80 \\
(1951)\end{array}$ & $\begin{array}{l}\text {...ползет / К по- } \\
\text { следней недопи- } \\
\text { санной странице. }\end{array}$ & только тень & $\begin{array}{l}\text { актер на } \\
\text { сцене }\end{array}$ & $\begin{array}{l}\text {...сказка в пере- } \\
\text { сказе / Глупца. } \\
\text { Она полна треску- } \\
\text { чих слов / И ниче- } \\
\text { го не значит. }\end{array}$ \\
\hline $\begin{array}{l}\text { Корнеев } \\
0,75 \\
(\mathbf{1 9 6 0 )}\end{array}$ & $\begin{array}{l}\text {...в книге жизни / } \\
\text { Читаем мы по- } \\
\text { следний слог... }\end{array}$ & только тень & комедиант & $\begin{array}{l}\text {...повесть, / Кото- } \\
\text { рую пересказал } \\
\text { дурак: / В ней } \\
\text { много слов и стра- } \\
\text { сти, нет лишь } \\
\text { смысла. }\end{array}$ \\
\hline $\begin{array}{l}\text { Лифшиц } \\
\mathbf{0 , 8 1} \\
\text { (1994) }\end{array}$ & $\begin{array}{l}\text { Разматывая сви- } \\
\text { ток бытия, / Кра- } \\
\text { дутся дни к итого- } \\
\text { вой ремарке... }\end{array}$ & Туман исчез. & $\begin{array}{l}\text { бездарный } \\
\text { лицедей }\end{array}$ & $\begin{array}{l}\text {...бессмысленная } \\
\text { сказка, / Расска- } \\
\text { занная круглым } \\
\text { идиотом, / Безум- } \\
\text { ный и бессвязный } \\
\text { монолог. }\end{array}$ \\
\hline
\end{tabular}




\begin{tabular}{|c|c|c|c|c|}
\hline $\begin{array}{l}\text { Рапопорт } \\
0,87 \\
(2000)\end{array}$ & $\begin{array}{l}\text {...вползают / К нам } \\
\text { незаметно через } \\
\text { поры бытия. }\end{array}$ & тень бродячая & $\begin{array}{l}\text { актер } \\
\text { несчастный }\end{array}$ & $\begin{array}{l}\text {...история, что рас- } \\
\text { сказал дурак, / } \\
\text { Наполненная яро- } \\
\text { стью и шумом, / } \\
\text { Которая не значит } \\
\text { ничего. }\end{array}$ \\
\hline $\begin{array}{l}\text { Флоря } \\
0,79 \\
\text { (2008) }\end{array}$ & $\begin{array}{l}\text { Дошла до эпилога / } \\
\text { Трагедия. }\end{array}$ & $\begin{array}{l}\text { призрак, бала- } \\
\text { ган пошлейший }\end{array}$ & марионетки & $\begin{array}{l}\text { Жизнь - новелла, } \\
\text { / Безумцем пере- } \\
\text { сказанная: бред / И } \\
\text { беснование. }\end{array}$ \\
\hline $\begin{array}{l}\text { Чернов } \\
1,13 \\
(2015)\end{array}$ & $\begin{array}{l}\text { И так до последне- } \\
\text { го слога Книги } \\
\text { су́деб. }\end{array}$ & плоская тень & $\begin{array}{l}\text { игра без- } \\
\text { дарного ак- } \\
\text { тера }\end{array}$ & $\begin{array}{l}\text { Бессмысленный } \\
\text { вопль, / Наполнен- } \\
\text { ный шумом и яро- } \\
\text { стью, / Сюжет, пе- } \\
\text { ресказанный идио- } \\
\text { том. }\end{array}$ \\
\hline
\end{tabular}

Переводчики предлагают разные интерпретации словосочетания "poor player", от стилистически нейтрального и близкого к оригиналу слова «актер» до «комедианта» и «фигляра», стремясь подчеркнуть значение «бедный, несчастный, жалкий, плохой». Но оригинал имеет еще значение «нищий», «ничего не имеющий», которое развивается у Шекспира на протяжении всего монолога. Диапазон употребления ключевых слов в данном фрагменте колеблется в пределах 6-7 слов, что не влияет на вариативность.

У русскоязычных переводчиков отсутствует самый значимый образаллегория, принадлежащий к топосам того времени, - образ Времени, который коррелирует со словом "life". Именно Время (прошлое, настоящее, будущее) - основной действующий персонаж в этом диалоге и во всей пьесе в целом. Тогда как в переводе монолога они сосредотачивают основное внимание на слове «жизнь». В ренессансной иконографии Время или Сатурн часто изображался крылатым стариком с атрибутами смерти (коса, череп и т. д.), а также в виде аллегорий трех возрастов жизни.

Возникает вопрос, почему Макбет сетует на то, что леди Макбет слишком рано ушла, несмотря на то, что ее разум уже помутился? С одной стороны, как правило, это связывают с тем, что Макбет лишился своей вдохновительницы и ее поддержки, но он ее лишился уже тогда, когда леди Макбет впала в сон, который открыл ей явность. Но ведь и сам Макбет видел призрака Банко, поэтому он мог не придавать этому значения. А если вспомнить реплику, где он говорит, что леди Макбет нужно рожать только сыновей («Рожай лишь сыновей. / С таким закалом должно создавать / Одних мужчин»; 
пер. М. Л. Лозинского), то в ее предназначение входило обеспечить передачу престола, иначе полученная такой ценой власть бессмысленна, поскольку власть продолжается в новом цикле - в жизни наследника (леди Макбет упоминает, что она кормила ребенка грудью).

С другой стороны, если обратиться к иконографии изображения Сатурна и рассмотреть его относительно человека, то она представлена как «Три возраста человеческой жизни», например, на картинах Тициана, Ханса Бальдунга, Джованни ди Лутеро, Джорджоне, Бронзино и др. Леди Макбет не вошла в третий возраст - старости, т. е. слово не было дописано, и летопись ее жизни была прервана. У Шекспира время - это мерило, а его символ - песочные часы - можно интерпретировать как христианский символ праха, из которого сотворен человек, т. е. время истощает его плоть и наступает "dusty death" (пыльная смерть, прах).

Время в монологе - это летописец, он записывает ежедневные шаги, которые становятся слогами, но в какую книгу она попадет? Большинство переводчиков избирают «книгу жизни». Именно она упоминается в Библии: «прости им грех их, а если нет, то изгладь и меня из книги Твоей, в которую Ты вписал» (Исх. 32:32); «враги мои все пред Тобою <..> да изгладятся они из книги живых и с праведниками да не напишутся» (Пс. 68:20-29); «И не войдет в него ничто нечистое и никто преданный мерзости и лжи, а только те, которые написаны у Агнца в книге жизни» (Откр. 21:27), «Побеждающий облечется в белые одежды; и не изглажу имени его из книги жизни, и исповедаю имя его пред Отцем Моим и пред Ангелами Его» (Откр. 3:1).

Эта цитата показывает суть галлюцинации леди Макбет, которая не может смыть кровь Дункана со своих рук: одежды запачканы, ее имя будет изглажено из книги жизни. В главе 5 «Откровения» также говорится о книге за семью печатями: «...достоин Ты взять книгу и снять с нее печати, ибо Ты был заклан, и Кровию Своею искупил нас Богу из всякого колена и языка, и народа и племени, и соделал нас царями и священниками Богу нашему; и мы будем царствовать на земле. И я видел, и слышал голос многих Ангелов вокруг престола и животных и старцев, и число их было тьмы тем и тысячи тысяч, которые говорили громким голосом: достоин Агнец закланный принять силу и богатство, и премудрость и крепость, и честь и славу и благословение. И всякое создание, находящееся на небе и на земле, и под землею, и на море, и все, что в них, слышал я, говорило: Сидящему на престоле и Агнцу благословение и честь, и слава и держава во веки веков. И четыре животных говорили: аминь. И двадцать четыре старца пали и поклонились Живущему во веки веков» (Откр. 5:9-14). Леди Макбет не попадает в эту книгу царствующих, от нее остается только прах (“dusty death”). 
Развитие сюжета пьесы соответствует словам из Откровения: «И поклонятся ему все живущие на земле, которых имена не написаны в книге жизни у Агнца, закланного от создания мира. Кто имеет ухо, да слышит. Кто ведет в плен, тот сам пойдет в плен; кто мечом убивает, тому самому надлежит быть убиту мечом. Здесь терпение и вера святых» (Откр. 13:8-10). Поэтому завершающая вторая половина концепта монолога связана с тем, что имеющие ухо не слышат, они сами разыгрывают спектакль, и их жизнь оказывается рассказом идиота, наполненным шумом и яростью / злобой (“sound and fury”).

Старость / смерть / старый человек часто изображались в преддверии могилы. И в свете могилы прожитая жизнь оказывается тенью. Монолог подчеркивает прожитую здесь и сейчас жизнь как вторичность, отраженность, проекцию, что напоминает платоновскую интерпретацию жизни человека. И человек, обреченный на смерть, тщится бросить ей вызов, он может продолжить себя во времени через славные деяния и через наследников. Чета Макбетов лишается того и другого, и колесо Фортуны делает свой очередной оборот.

\section{ЗАКЛЮЧЕНИЕ}

Если рассматривать перевод как социокультурную практику, которая показывает его вектор в изменяющихся исторических, идеологических, социокультурных, стилистических и религиозных условиях, то мы можем сделать вывод, что в случае с «Макбетом» они не оказали существенного влияния на вариативность, измеряемую математически при помощи приложений и программ, визуализирующих различные метаданные (Чизман, 2015; Лисович, 2017: 142). Даже не смотря на то, что переводчики XXI века намеренно избегают повторять версии предшественников, они остаются в рамках среднего значения вариативности 0,8. Так, например, переводы фразы "walking shadow" хотя и варьируются от «тени» до «мечты» и «тумана», однако показатели Viv большинства переводов монолога Макбета находятся в пределах $0,7-0,8$.

Таким образом, степень вариативности переводов «Макбета» У. Шекспира можно выявить при помощи онлайн-платформы Version Variation Visualization (VVV), которая предлагает математический инструментарий для сравнения и ранжирования выравненных переводов. Как показывает опыт использования этой платформы на немецкоязычном материале, описанный Т. Чизманом (Cheesman, 2015; Чизман, 2015), и представленный в данной статье анализ 16 русскоязычных переводов «Макбета», платформа может дать исследователю возможность изучать переводы в визуализирован- 
ной среде и почву для интерпретаций как текстов переводов в целом, так и их отдельных сегментов.

\section{СПИСОК ЛИТЕРАТУРЫ}

Бурдье, П. (2001) Практический смысл / пер. с фр.: А. Т. Бикбов и др. ; отв. ред. пер. и послесл. Н. А. Шматко. СПб. : Алетейя. 562 с.

Гайдин, Б. Н. (2015) Разработка программы сравнительного тезаурусного анализа русских переводов произведений У. Шекспира (ответ на доклад Т. Чизмана «Текстовые массивы перевода: версия, вариация, визуализация») // Шекспир в междисциплинарных гуманитарных исследованиях : коллективная монография по материалам Международного научного семинара / ред.-сост. В. С. Макаров, Н. В. Захаров, Б. Н. Гайдин. М. : Изд-во Моск. гуманит. ун-та. 238 с. С. 147-155.

Гайдин, Б. Н. (2017) Онлайн-программа сравнительного тезаурусного анализа русских переводов произведений У. Шекспира: итоги первого года [Электронный ресурс] // Горизонты гуманитарного знания. № 6. С. 169182. URL: http://journals.mosgu.ru/ggz/article/view/649 (дата обращения: 01.12. 2018). DOI: $10.17805 / g g z .2017 .6 .10$

Захаров, Н. В. (2017) Сравнительный анализ русских переводов первой сцены «Меры за меру» У. Шекспира [Электронный ресурс] // Горизонты гуманитарного знания. № 6. C. 103-134. URL: http://journals.mosgu.ru/ggz/article/ view/646 (дата обращения: 01.12.2018). DOI: 10.17805/ggz.2017.6.7

Лисович, И. И. (2017) «Макбет» У. Шекспира и проблема вариативности русских переводов 30-60 гг. XX века [Электронный ресурс] // Горизонты гуманитарного знания. № 6. С. 135-152. URL: http://journals.mosgu.ru/ggz/ article/view/647 (дата обращения: 01.12.2018). DOI: 10.17805/ggz.2017.6.8

Макаров, В. С. (2017) «Бесплодные усилия любви» в русских переводах: опыт сравнительного анализа [Электронный ресурс] // Горизонты гуманитарного знания. № 6. C. 85-102. URL: http://journals.mosgu.ru/ggz/article/ view/642 (дата обращения: 01.12.2018). DOI: 10.17805/ggz.2017.6.6

Чизман, Т. (2015) Массивы переводов и их цифровое истолкование // Шекспир в междисциплинарных гуманитарных исследованиях : коллективная монография по материалам Международного научного семинара / ред.сост. В. С. Макаров, Н. В. Захаров, Б. Н. Гайдин. М. : Изд-во Моск. гуманит. ун-та. 238 с. С. $114-146$.

Cheesman, T. (2015) Reading originals by the light of translations // Shakespeare Survey. Vol. 68. P. 87-98.

Дата поступления: 10.12.2018 2.

Лисович Инна Ивановна - доктор культурологии, кандидат филологических наук, заместитель начальника отдела основных и дополнительных образовательных программ учебно-методического управления Российской ака- 
демии народного хозяйства и государственной службы при Президенте РФ; профессор кафедры философии, культурологии и политологии Московского гуманитарного университета. Адрес: 119571, Россия, г. Москва, пр-т Вернадского, 82, стр. 1. Тел.: +7 (499) 956-99-99. Эл. адрес: mag-inna@yandex.ru

Lisovich Inna Ivanovna, Doctor of Culturology, Candidate of Philology; Deputy Head, Department of Basic and Additional Educational Programs, Educational and Methodological Board, Russian Presidential Academy of National Economy and Public Administration; Professor, Department of Philosophy, Culturology and Politology, Moscow University for the Humanities. Postal address: Bldg. 1, 84 Prospekt Vernadskogo, 119571 Moscow, Russian Federation. Tel.: +7 (499) 956-99-99. E-mail: mag-inna@yandex.ru

\section{Для циитирования:}

Лисович И. И. "Life’s but a walking shadow, a poor player": проблема вариативности русских переводов пьесы «Макбет»У. Шекспира [Электронный ресурс] // Горизонты гуманитарного знания. 2018. № 6. С. 123-143. URL: http://journals.mosgu.ru/ggz/article/view/896 (дата обращения: дд.мм.гггг). DOI: 10.17805/ggz.2018.6.9 